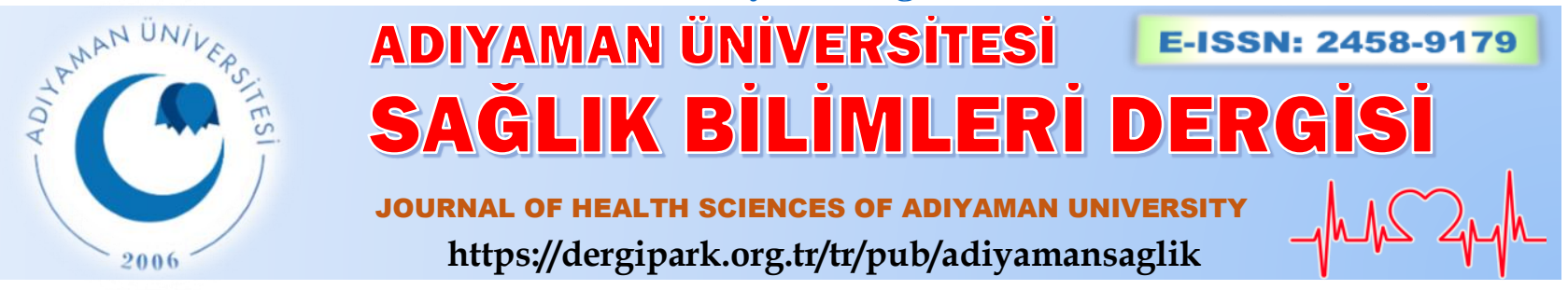

Sistematik Derlemeler ve Meta Analiz/Systematic Reviews and Meta Analysis

\title{
Türkiye'de ebe ve hemşirelerin kendi kendine meme muayenesi ile ilgili yaptığı lisansüstü tezlerin incelenmesi
}

\section{An examination of the graduate theses about breast self-examination by midwifes and nurses in Turkey}

\author{
Seda SERHATLIOĞLU1@(D), Nuran GENÇTÜRK ${ }^{2}$ \\ ${ }^{1}$ İstanbul Üniversitesi-Cerrahpaşa, Lisansüstü Eğitim Enstitüsü, Ebelik Anabilim Dal1, 34320, İstanbul-Türkiye \\ ${ }^{2}$ İstanbul Üniversitesi-Cerrahpaşa, Sağlık Bilimleri Fakültesi, Ebelik Bölümü, 34320, İstanbul-Türkiye
}

Atıf gösterme/Cite this article as: Serhatlığlu S, Gençtürk N. Türkiye'de ebe ve hemşirelerin kendi kendine meme muayenesi ile ilgili yaptığı lisansüstü tezlerin incelenmesi. ADŸ̈ Sağllk Bilimleri Derg. 2020;6(3):367-379. doi:10.30569.adiyamansaglik. 750463

Öz

Amaç: Ebe ve hemşirelerin Kendi Kendine Meme Muayenesi (KKMM) ile ilgili yaptıkları lisansüstü tezlerin özelliklerini belirlemek ve gelişmeleri ortaya koymak amaçlanmıştır.

Gereç ve Yöntem: Çalışma retrospektif tipte literatüre dayalı tanımlayıcı olarak yapılmıştır. Yüksek Öğretim Kurumu (YÖK) Tez Tarama veri tabanı 25 Aralık 2019-25 Ocak 2020 tarihleri arasında "kendi kendine meme muayenesi" anahtar kelimesi kullanılarak tarandı. Çalışmaya 1985-2019 yılları arasında hazırlanan 20 tez dahil edildi.

Bulgular: Tezlerin tamamına yakınının (\%90) yüksek lisans tezi olduğu, \%15'inin 2019 yılında hazırlandı̆̆ 1 , \%30’unun Cerrahi Hemşireliği Anabilim Dalı'nda yürütüldüğü belirlendi. Tanımlayıcı tipte hazırlanan tezlerin fazla olduğu (\%60) ve araştırmalarda veri toplama aracı olarak anket ve ölçeklerin kullanıldığı görüldü.

Sonuç: Çalışmanın uygulandığı örneklem grubu kim olursa olsun, KKMM ile ilgili bilgi, tutum eksikliği ve aynı zamanda KKMM'yi uygulamaya devam etmede sıkıntı tespit edilmiştir. KKMM farkındalığı ve becerisi kazandıran lisansüstü tezlerin sayılarının arttırılması önerilmektedir.

Anahtar Kelimeler: Erken tanı; Kendi kendine meme muayenesi; Meme kanseri; Tez inceleme.

\begin{abstract}
Aim: It was conducted to examine the postgraduate theses by midwives and nurses on Breast SelfExamination (BSE).

Materials and Methods: The study was conducted as a retrospective type descriptive based on the literature. Higher Education Institution (HEI) Thesis Search database was searched between 2 January and 25 January using the keyword "breast self-examination". Twenty theses prepared between 1985 and 2019 were included in the study.

Results: It was determined that almost all $(90 \%)$ of the theses included in the study were master's theses, $15 \%$ were prepared in 2019 and $30 \%$ of theses conducted in the Department of Surgical Nursing. It is seen that the theses prepared in descriptive type are high (60\%) and surveys and scales are used as data collection tools.

Conclusion: According to the results of the study, regardless of the sample group to which the study was applied, it was determined that there was a lack of knowledge and attitude regarding BSE and difficulties in continuing the application. It is recommended to increase the number of postgraduate theses that give BSE awareness and skill.
\end{abstract}

Keywords: Breast cancer; Breast self-examination; Early diagnosis; Thesis review.

Yazışma Adresi/Address for Correspondence: Seda SERHATLIOĞLU, Karabük Üniversitesi, Demir Çelik Kampüsü, Sağlık Bilimleri Fakültesi, 78100, Karabük-Türkiye, E-mail: sedagoncu07@gmail.com

Geliş Tarihi/Received:10.06.2020 Kabul Tarihi/Accepted:14.09.2020

Yayım Tarihi/Published online:03.12.2020

Bu eser, Creative Commons Atıf-GayriTicari 4.0 Uluslararası Lisansı ile lisanslanmıștır. Telif Hakkı @ 2020 Adıyaman Üniversitesi Rektörlüğü 


\section{Giriş}

Kanser son zamanlarda en korkutan ve en s1k görülen hastalık olarak karşımıza çıkmaktadır. Tüm dünyadaki ölümlere bakıldığında ikinci ölüm nedeni ve gerçekleşen altı ölümden biri kanser kaynaklıdır. ${ }^{1}$ Türkiye'de de her beş ölümden biri kanser nedeniyle meydana gelmektedir. ${ }^{2}$ Kanser çeşitleri arasında hayatı tehdit eden meme kanseri ise, kadın nüfusu içinde önde gelen ölüm nedenidir. ${ }^{1,3}$

Kadınlarda görülen kanserlerin başında yer alan meme kanseri, her yıl kadın kanserleriyle ilgili ölümlerin çoğuna neden olmaktadır. ${ }^{4}$ Uluslararası Kanser Ajansı (IARC) tarafindan yayınlanan GLOBOCAN 2018 verilerinde dünya genelinde tüm kanser vakalarının $\% 25$ 'ini, kansere bağlı ölümlerin de \%15'ini meme kanserinin oluşturduğu bildirilmiştir. ${ }^{1}$ Türkiye'de 2015 yılı verilerine göre meme kanseri insidans1, yüz binde 43,8 olarak saptanmıştır. Kanser tanısı konulan her dört kadından biri meme kanseridir. ${ }^{5}$ Meme kanserinde erken tan1; mortalite ve morbiditeyi azaltmanın en etkili yoludur. Meme kanserinin en sık görülen kanser türü olması ve kansere bağlı ölümlerde birinci sırada yer alması erken tanı ve tedavinin önemini göstermektedir. Meme kanserinin erken tanılanması ve tedavinin erken süreçte başlaması kadının yaşam kalitesini arttırmakta ve yaşam süresini uzatmaktadır. Uluslararası Kanser Ajans1 (IARC)'ndan elde edilen kanıtlar, teknoloji ve erken tanı yöntemleriyle 20 yıl içinde kanser vakalarının 1/4'ünün önlenebilir olduğunu, 3/4'ünün ise tedavisinin mümkün olduğunu savunmaktadır. ${ }^{1}$

Meme kanseri erken tanısı için kullanılan yöntemler arasında Mamografi, Klinik Meme Muayenesi (KKM) yaptırma ve Kendi Kendine Meme Muayenesi (KKMM) yapma yer almaktadır. Türkiye Halk Sağlığı Kurumu Kanser Daire Başkanlığı tarama rehberine göre kadınların; 20-40 yaş arası ayda bir KKMM, 2 yılda bir KMM, 40-69 yaş arası ayda bir KKMM, her yıl KMM, yılda 2 defa bir mamografi çektirilmesini tavsiye etmektedir. $^{6}$ KKM, sağlık profesyoneli tarafından mamografi çektirmenin sınırlı olduğu durumlarda inspeksiyon ve palpasyon yöntemleriyle memelerin şekil, büyüklük, renk, şişkinlik, çukurlaşma gibi değişiklikler yönünden değerlendirilmesi ve koltuk altı muayenesinden oluşmaktadır. ${ }^{7}$ Mamografi, meme dokusunun $\mathrm{X}$ 1şınları yardımıyla görüntülenmesi işlemidir. Erken aşamada belirti vermeyen oluşumların tespitinde etkili bir tanılama yöntemidir. ${ }^{6}$ Kadınların meme kanseri erken tanısı için ayda bir kere memelerini sistematik bir şekilde, belirtilen yöntemlerle muayene etmesine KKMM denir. Düzenli bir şekilde KKMM yapmak kadının memesinin normal görünüm ve dokusuna alıșmasını sağlar, böylelikle normalden sapma durumunu kolaylıkla ayırt edebilir.,

KKMM basit, ekonomik, araç-gereç gerektirmeyen, kolay, zararsız, kadının mahremiyetinin korunduğu, zaman almayan, kadınların evinde tek başına kolaylıkla uygulayabileceği, girişim gerektirmeyen bir yöntem olmasından dolayı meme kanserinin tanılanmasında oldukça büyük öneme sahiptir $^{10}$. Erken tanının kadınların kendileri tarafından sağlanabilmesi için KKMM'yi öğretmek, gerekliliğinin önemini kavratmak sağllk profesyonellerinin primer sorumluluğundadır. Erken tanı ve tedavi ile yaşam kalitesinin arttırılacağı ve yaşam süresinin uzatılacağının göz önüne alınması, KKMM ile ilgili yapılan çalışmalara önem verilmesi gerektiğini ortaya koymaktadır. Yapılan çalışmaların sonuçlarını değerlendirmek kadınların farkındalık düzeylerini arttırmak ve yetersizlikleri görmek açısından önemlidir. Geçmişten günümüze KKMM ile ilgili yapılan lisansüstü tezlerin gözden geçirilmesinin ve konu ile ilgili durumun ortaya konulmasının araştırma önceliklerinin belirlenmesi açısından önemli olacağı gibi aynı zamanda KKMM ile ilgili yapılacak yeni çalışmalara 1şık tutacaktır.

Meme kanserinin erken tanı ve tedavisinde önemli yeri olan KKMM ile ilgili literatürde yapılan tezleri inceleyen çalışmaya rastlanmamıştır. $\mathrm{Bu}$ motivasyonla bu çalışmada; Türkiye'de ebe ve hemşireler tarafindan yapılan ve "kendi kendine meme muayenesi" anahtar kelimesini içeren yüksek lisans ve doktora tezlerini incelemek, tezlerin özelliklerini belirlemek, alandaki gelişmeleri ve eksiklikleri ortaya koymak amaçlanmıştır. 
Çalışmada aşağıda belirtilen alt amaçlara ulaşılması hedeflenmiştir:

- Türkiye'de ebe ve hemşirelerin KKMM ile ilgili yaptıkları lisansüstü tezler hangi yıllarda yayınlanmıştır?

- Türkiye'de ebe ve hemşirelerin KKMM ile ilgili yaptıkları lisansüstü tezler hangi anabilim dallarına aittir?

- Türkiye'de ebe ve hemşirelerin KKMM ile ilgili yaptıkları lisansüstü tezlerin türleri nedir?

- Türkiye'de ebe ve hemşirelerin KKMM ile ilgili yaptıkları lisansüstü tezlerin araştırma yöntemleri nelerdir?

- Türkiye'de ebe ve hemşirelerin KKMM ile ilgili yaptıkları lisansüstü tezlerde hangi örneklem gruplarıyla çalışılmıştır?

- Türkiye'de ebe ve hemşirelerin KKMM ile ilgili yaptıkları lisansüstü tezlerde örneklem sayıları kaçtır?

- Türkiye'de ebe ve hemşirelerin KKMM ile ilgili yaptıkları lisansüstü tezlerde veri toplama aracı olarak kullanılan formlar nelerdir?

- Türkiye'de ebe ve hemşirelerin KKMM ile ilgili yaptıkları lisansüstü tezlerin sonuç özellikleri nelerdir?

\section{Gereç ve Yöntem}

\section{Araştırmanın tipi}

Çalışma, meme kanserinin erken teşhisinde çok büyük öneme sahip olan KKMM yöntemi konusunda ebe ve hemşireler tarafindan yapılan lisansüstü tezleri retrospektif olarak inceleyen literatüre dayalı tanımlayıcı bir çalışmadır.

\section{Araştırmanın evreni ve örneklemi}

Araştırmanın evrenini Yükseköğretim Kurulu Ulusal Tez Merkezi'nin "kendi kendine meme muayenesi" anahtar kelimesi ile taranmasi sonucu bulunan 31 adet tez oluşturmaktadır. Araştırmaya dâhil edilen 20 tezin iki tanesi doktora, 18 tanesi yüksek lisans tezidir.

Çalışmaya dahil edilme kriterleri;

- "kendi kendine meme muayenesi" kelimelerinin tezin başlığında yer alması

- Tezlerin yayınlanmış olması
- Tezlerin ebelik ya da hemşirelik anabilim dallarına ait olması

- Tezlerin tam metnine ulaşılabilir olması

Çalışmanın dışlanma kriterleri;

- Tezin başlığında "kendi kendine meme muayenesi" geçmesine rağmen farklı disiplinler tarafından yapılmış olması

- Yayın dilinin Türkçe olmaması

\section{Veri toplama araçları}

Çalışma verileri, Yüksek Öğretim Kurumu (YÖK) Ulusal Tez Merkezi veri tabanına erişilerek toplanmıştır. Tarama 25 Aralık 201925 Ocak 2020 tarihleri arasında yapılmıştır. Çalışmada, 1985- 2019 yılları arasında YÖK Tez Tarama veri tabanında Aranacak Kelime(ler) kısmina "kendi kendine meme muayenesi" anahtar kelimesi yazılarak ve Aranacak Alan kısmı "tez adı" seçilerek arama yapılmıştır. Arama sonucunda 31 adet tez bulunmuştur. Araştırmaya dahil edilme kriterlerinden tam metnine ulaşılması şartını sağlamayan 5 tez, ebelik ve hemşirelik dışında başka bir anabilim dalına ait olan 6 tez çalışma dişı bırakılmıştır. Çalışmada toplam 20 tez değerlendirme kapsamına alınmış ve yayınlandıkları yıl, tür, anabilim dalı, yöntem, çalışılan örneklem grubu ve sayısı, ölçüm araçları ve sonuç özellikleri bakımından incelenmiştir. Verilerin toplanmasında ve kodlanmasında oluşturulan Microsoft Excel tablosu kullanılmıştır.

\section{Verilerin analizi}

Tezler araştırmacılar tarafından geliştirilen sekiz maddelik soru formu ile değerlendirilmiştir. Tezin yılı, anabilim dalı, türü, örneklem grubu, örneklem sayısı, araştırma yöntemi, ölçme araçları ve sonuçlarına yönelik cevap aranmıştır. Verilerin değişkenlere göre frekans (n) ve yüzdelik (\%) hesapları yapılmış ve veriler grafikler şeklinde sunulmuştur.

\section{Araştırmanın etik boyutu}

$\mathrm{Bu}$ araştırmanın etik kurul raporu bulunmamaktadır. Yüksek Öğretim Kurumu ulusal tez merkezi sayfasından erişim izni olan 20 tez kullanılmış, erişim izni olmayan tezler çalışmaya alınmamıştır. 


\section{Bulgular}

YÖK veri tabanının "kendi kendine meme muayenesi" kelimeleriyle tez adı kısmında arama $(\mathrm{n}=31)$

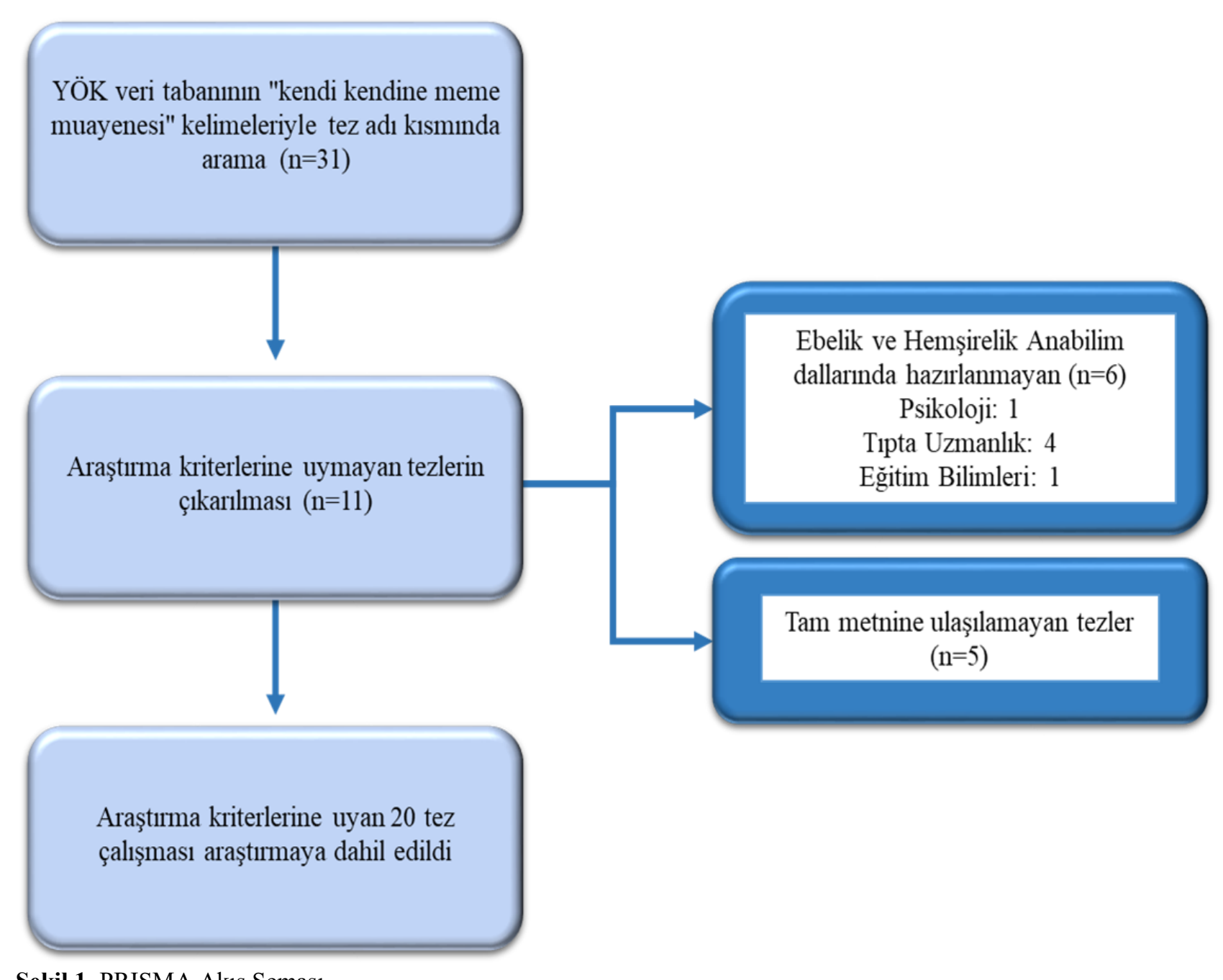

Şekil 1. PRISMA Akış Şeması

Türkiye'de ebe ve hemşirelerin KKMM ile ilgili yaptığı lisansüstü tezlerin incelendiği çalışmaya göre; tezlerin yıllara göre dağılımına bakıldığında 1985 yılında ilk tezin hazırlandığı ve 2002 yılına kadar KKMM ile ilgili başka tezin hazırlanmadığı görülmüştür. Bazı yıllarda bu konuda hiç tez hazırlanmadığı, en fazla tezin (n=3) 2019 yılında hazırlandığı görülmektedir (Şekil 2).

Şekil 3'te yer alan lisansüstü tezlerin yapıldıkları anabilim dalı dağılımına göre, tezlerin üçte birinin (\%30) Cerrahi Hemşireliği Anabilim Dalı'nda yürütüldüğü görülmektedir. Diğerleri Halk Sağlı̆̆ı/Halk Sağlığı Hemşireliği, İç Hastalıkları Hemşireliği, Hemşirelik, Ebelik ve Kadın Hastalıkları ve Doğum Anabilim Dalları'nda hazırlanmıştır.

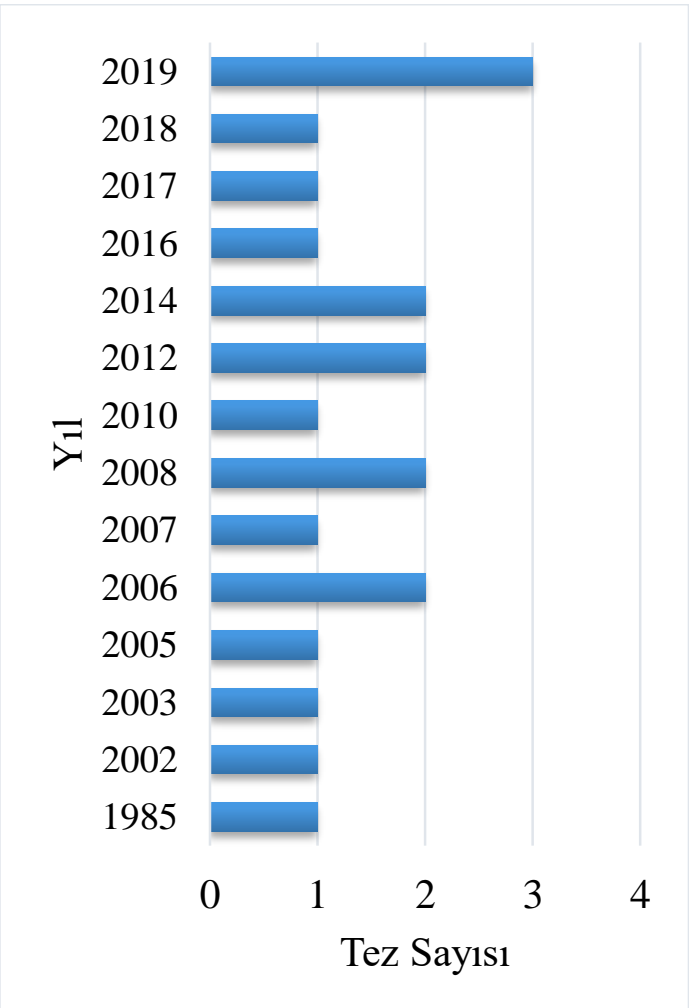

Şekil 2. Yıllara Göre Tezlerin Dağılımı 


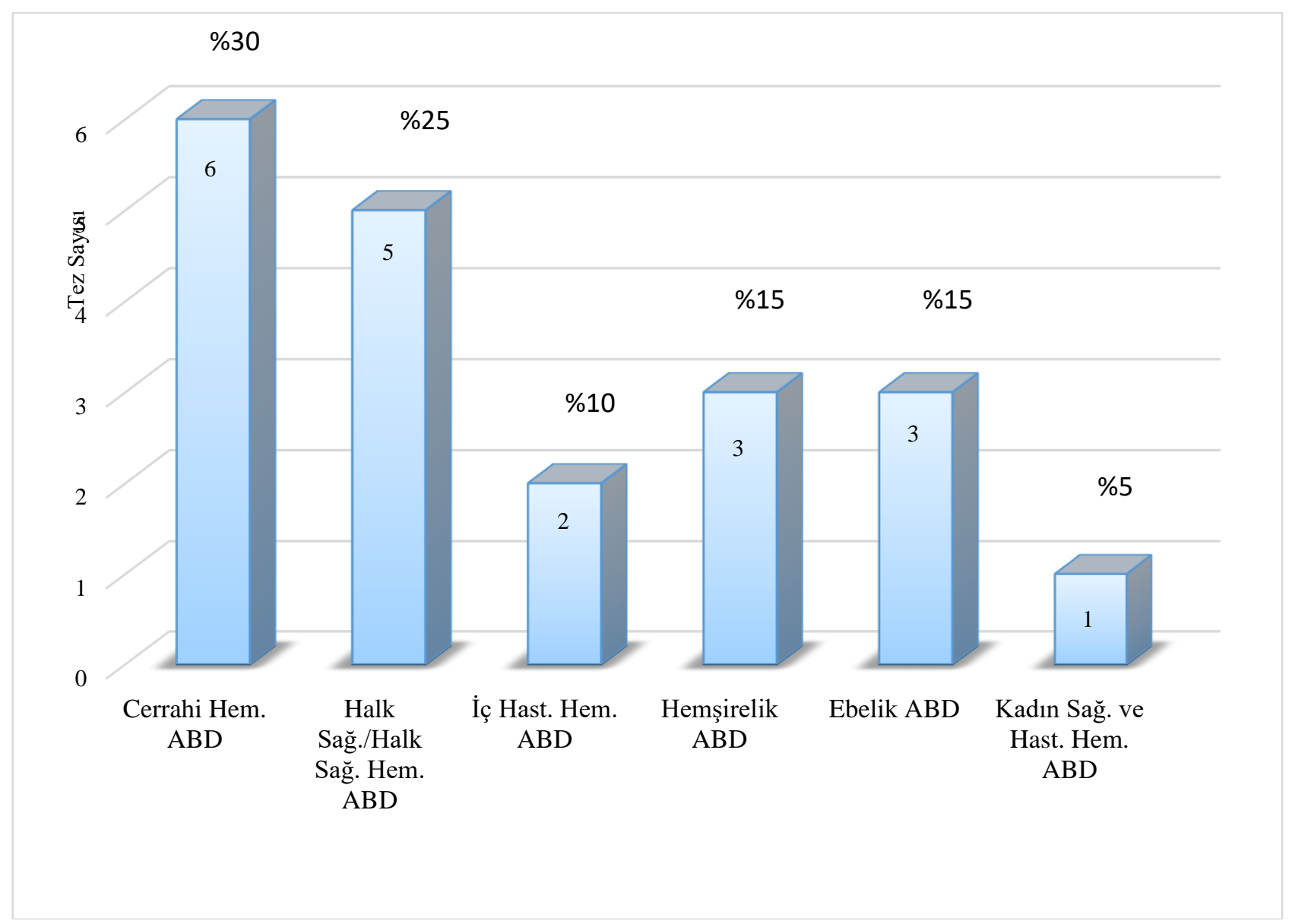

Şekil 3. Tezlerin Anabilim Dallarına Göre Dağılımı

Tezlerin türlerine göre dağılımları incelendiğinde, \%90'ının yüksek lisans tezi olduğu, sadece iki tanesinin doktora tezi olduğu görülmektedir (Şekil 4). Doktora tezlerinin biri Cerrahi Hastalıkları Hemşireliği Anabilim Dalı'nda, diğeri ise Halk Sağlığ Anabilim Dalı'nda hazırlanmıştır.

Örnekleme alınan lisansüstü tezler araştırma yöntemlerine göre incelendiğinde; \%60'ının tanımlayıc1, \%20'sinin yarı deneysel, \%10'unun deneysel, \%5'inin kesitsel, \%5'inin tanımlayıcı-müdahale yöntemleriyle yapıldı̆̆ı görülmektedir (Şekil 5).

Çalışmaya dahil edilen tezlerin örneklem gruplarının sağlıklı kadınlar, meme kanseri tanılı hastalar, kız öğrenciler, kadın akademisyenler, sağlık çalışanı kadınlar, mahkûm kadınlar, işitme engelli kadınlar, görme engelli kadınlar ve memede kitle şikâyeti olan kadınlardan oluştuğu görülmektedir. Örneklem sayıları 62 (min.)1000 (max.) arasında değişmektedir (Tablo $1)$.
Araştırmalarda veri toplama aracı olarak anket ve ölçekler kullanılmıştır (Tablo 1). Kullanılan ölçekler ise; Champion Sağlık İnanç Modeli Ölçeği, Champion Meme Kanseri Korku Ölçeği, Nottingham Sağlık Profili (NHP) ve Coopersmith Benlik Saygis1 Ölçeği'dir.

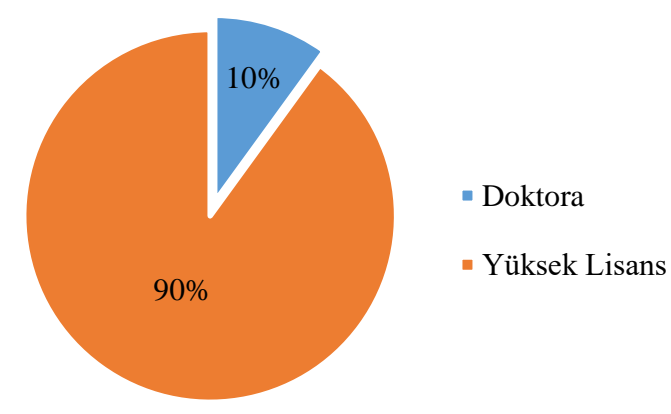

Şekil 4. Tezlerin Türüne Göre Dağılımı 


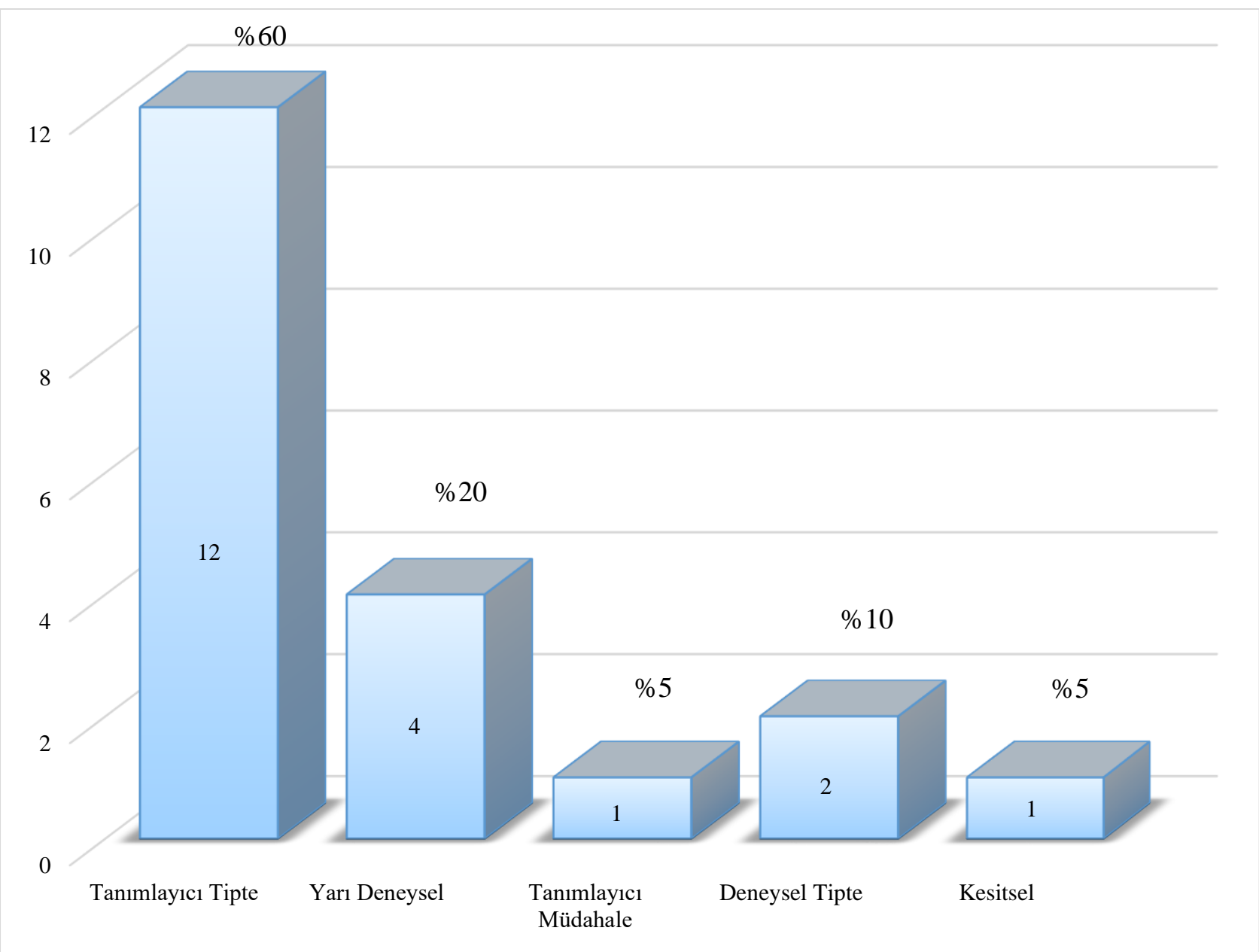

Şekil 5. Tezlerin Yöntemlerine Göre Dağılımı

Tablo 1. Tezlerin Bazı Değişkenlere Göre Dağılımı

\begin{tabular}{|c|c|c|c|c|c|}
\hline Yazar & Yil & Örneklem Grubu & Çalışmanın Tipi & Kullanılan araçlar & Sonuç \\
\hline Akyolcu $^{21}$ & 1985 & $\begin{array}{l}100 \text { Meme kanseri } \\
\text { tanılı hasta kadın } \\
100 \text { Sağlıklı kadın }\end{array}$ & Tanımlayıcı & $\begin{array}{l}\text { Araştırmacı } \\
\text { tarafindan } \\
\text { hazırlanan anket } \\
\text { formu }\end{array}$ & $\begin{array}{l}\text { Çalışmaya katılan kadınların } \\
\text { meme kanseri ve kendi } \\
\text { kendine meme muayenesi } \\
\text { konusundaki bilgilerinin } \\
\text { yetersiz olduğu saptanmıştır. }\end{array}$ \\
\hline Tuna $^{22}$ & 2002 & $\begin{array}{l}150 \text { Üniversite } \\
\text { öğrencisi }\end{array}$ & Yarı deneysel & $\begin{array}{l}\text { KKMM Bilgi } \\
\text { Değerlendirme } \\
\text { Formu 1-11 } \\
\text { KKMM Uygulama } \\
\text { Becerisini } \\
\text { Değerlendirme } \\
\text { Formu, } \\
\text { KKMM Düzenli } \\
\text { Uygulama } \\
\text { Durumunu } \\
\text { Değerlendirme } \\
\text { Formu }\end{array}$ & $\begin{array}{l}\text { Üniversite öğrencilerinin } \\
\text { kendi kendine meme } \\
\text { muayenesini öğrenmelerinde } \\
\text { akran eğitiminin etkili } \\
\text { olduğu bulunmuştur. }\end{array}$ \\
\hline $\begin{array}{l}\text { Gökpınar } \\
\text { Çevik }^{10}\end{array}$ & 2003 & 62 Kadın & Tanımlayıc1 & $\begin{array}{l}\text { Araştırmacı } \\
\text { tarafından } \\
\text { hazırlanan anket } \\
\text { formu }\end{array}$ & $\begin{array}{l}\text { Kadınların meme kanseri ve } \\
\text { kendi kendine meme } \\
\text { muayenesi ile ilgili bilgi } \\
\text { düzeylerinin düşük } \\
\text { olduğunu, kendi kendine } \\
\text { meme muayenesini her ay } \\
\text { düzenli yapmadıklarını, } \\
\text { memelerindeki kitleleri } \\
\text { tesadüfen fark ettikleri } \\
\text { bulunmuştur. }\end{array}$ \\
\hline
\end{tabular}




\begin{tabular}{|c|c|c|c|c|c|}
\hline Harputlu $^{12}$ & 2005 & $\begin{array}{l}161 \text { Kadın } \\
\text { mahkum }\end{array}$ & $\begin{array}{l}\text { Tanımlayıcı ve } \\
\text { ilişkisel }\end{array}$ & $\begin{array}{l}\text { Araştırmacılar } \\
\text { tarafından } \\
\text { hazırlanan anket } \\
\text { formu, } \\
\text { Coopersmith } \\
\text { Benlik Saygısı } \\
\text { Ölçeği }\end{array}$ & $\begin{array}{l}\text { Kadın mahkumların KKMM } \\
\text { bilgi ve uygulamalarının } \\
\text { yetersiz olduğu } \\
\text { belirlenmiştir. }\end{array}$ \\
\hline Canbulat $^{11}$ & 2006 & 268 Sağlık çalışanı & Tanımlayıcı & $\begin{array}{l}\text { Araştırmacılar } \\
\text { tarafindan } \\
\text { hazırlanan anket } \\
\text { formları, } \\
\text { Meme Kanseri } \\
\text { taramalarında } \\
\text { Champion Sağlık } \\
\text { İnanç Modeli } \\
\text { Ölçeği }\end{array}$ & $\begin{array}{l}\text { Sağlık çalışanlarının büyük } \\
\text { çoğunluğunun KKMM } \\
\text { yapma zamanına önem } \\
\text { göstermedikleri, konuya } \\
\text { ilişkin tutum ve } \\
\text { davranışlarında değişim } \\
\text { göstermeleri için hizmet içi } \\
\text { eğitim programlarına işlerlik } \\
\text { kazandırılması sonucuna } \\
\text { varılmıştır. }\end{array}$ \\
\hline Elik $^{23}$ & 2006 & $\begin{array}{l}42 \text { deney } \\
48 \text { kontrol } \\
\text { Ev hanımı }\end{array}$ & Yarı deneysel & $\begin{array}{l}\text { Kadınların Sosyo- } \\
\text { Demografik } \\
\text { Özellikleri ve } \\
\text { Meme Kanseri } \\
\text { Riski Anket Formu, } \\
\text { KKMM Bilgi ve } \\
\text { Uygulama Durumu } \\
\text { Kontrol Formu, } \\
\text { Champion Sağlık } \\
\text { İnanç Modeli } \\
\text { Ölçeği }\end{array}$ & $\begin{array}{l}\text { Eğitim sonrasında sağlık } \\
\text { inançları boyutlarından } \\
\text { sağlı motivasyonu ve } \\
\text { KKMM yararları dışındaki } \\
\text { boyutlarda iki grup arasında } \\
\text { anlamlı bir fark bulunmuştur. } \\
\text { Çalışma sonucunda yapılan } \\
\text { eğitimin, KKMM bilgi ve } \\
\text { uygulamaları ile meme } \\
\text { sağlığı ile ilgili inançları } \\
\text { artmıştır. }\end{array}$ \\
\hline Arslan $^{13}$ & 2007 & 200 Kadın & Tanımlayıcı Tipte & $\begin{array}{l}\text { Araştırmacılar } \\
\text { tarafından } \\
\text { hazırlanan anket } \\
\text { formu }\end{array}$ & $\begin{array}{l}\text { Eğitim öncesi ve eğitim } \\
\text { sonrası bilgi düzeyi puan } \\
\text { ortalamaları arasında } \\
\text { istatistiksel olarak anlamlı } \\
\text { farklılık saptanmıştır. }\end{array}$ \\
\hline Taşç1 ${ }^{14}$ & 2008 & $\begin{array}{l}252 \text { Kadın } \\
29 \text { Ebe / Hemşire }\end{array}$ & Tanımlayıcı Tipte & $\begin{array}{l}\text { Araştırmacılar } \\
\text { tarafindan } \\
\text { hazırlanan anket } \\
\text { formları }\end{array}$ & $\begin{array}{l}\text { Kadınların çoğunluğunun } \\
\text { KKMM yapmadığı, } \\
\text { Hemşirelerin tamamına } \\
\text { yakınının KKMM yaptığı } \\
\text { saptanmıştır. }\end{array}$ \\
\hline Duran $^{27}$ & 2008 & $\begin{array}{l}31 \text { Mahkum } \\
36 \text { Halk Eğitim } \\
\text { Merkezine devam } \\
\text { eden kadın } \\
\text { 41 Kuran kursuna } \\
\text { devam eden kadın }\end{array}$ & Deneysel Tipte & $\begin{array}{l}\text { Sosyo-demografik } \\
\text { soru formu, } \\
\text { Türkçe Champion } \\
\text { Sağlık İnanç } \\
\text { Modeli Ölçeği, } \\
\text { Nottingham Sağlık } \\
\text { Profili } \\
\text { (NHP) }\end{array}$ & $\begin{array}{l}\text { Meme kanserinde erken } \\
\text { tanıya yönelik davranışlar } \\
\text { açısından, KKMM yapma, } \\
\text { klinik meme muayenesi } \\
\text { (KMM) yaptırma ve } \\
\text { mamografi çektirme } \\
\text { oranlarının düşük düzeyde } \\
\text { olduğu saptanmıştır. }\end{array}$ \\
\hline Kersu $^{32}$ & 2010 & 1000 Kadın & $\begin{array}{l}\text { Tanımlayıcı- } \\
\text { müdahale } \\
\text { çalışması }\end{array}$ & $\begin{array}{l}\text { Anket formunun ilk } \\
\text { bölümde } \\
\text { sosyodemografik } \\
\text { özellikleri içeren } \\
\text { sorular, ikinci } \\
\text { bölümde KKMM } \\
\text { bilgi düzeyini } \\
\text { belirleyen sorular, } \\
\text { üçüncü bölümde } \\
\text { KKMM uygulama } \\
\text { durumunu } \\
\text { belirleyen sorular }\end{array}$ & $\begin{array}{l}\text { Eğitim öncesi ve eğitimden } \\
\text { sonra KKMM bilgi puan } \\
\text { ortalamaları (BPO) ve } \\
\text { uygulama puan ortalamaları } \\
\text { (UPO) arasında önemli fark } \\
\text { olduğu saptanmıştır } \\
(\mathrm{p}<0,001) .\end{array}$ \\
\hline Öktem ${ }^{15}$ & 2012 & $200 \mathrm{~K} 1 \mathrm{z}$ öğrenci & Tanımlayıcı & $\begin{array}{l}\text { Araştırmacılar } \\
\text { tarafindan } \\
\text { hazırlanan anket } \\
\text { formları }\end{array}$ & $\begin{array}{l}\text { Öğrencilerin meme kanseri } \\
\text { risk faktörleri, belirtileri ve } \\
\text { KKMM hakkında yeterli } \\
\text { bilgiye sahip olmadıkları }\end{array}$ \\
\hline
\end{tabular}




\begin{tabular}{|c|c|c|c|c|c|}
\hline & & & & & $\begin{array}{l}\text { saptanmıştır. KKMM } \\
\text { uygulamasının doğru } \\
\text { zamanını ve yöntemini } \\
\text { bilmedikleri sonucu } \\
\text { çkarılabilir. }\end{array}$ \\
\hline Ceylan $^{20}$ & 2017 & $\begin{array}{l}553 \text { Kadın sağlık } \\
\text { çalışanı }\end{array}$ & Tanımlayıcı Tipte & $\begin{array}{l}\text { Kişisel Bilgi Formu } \\
\text { ve Türkçe } \\
\text { Champion Sağlık } \\
\text { İnançları Modeli } \\
\text { Ölçeği }\end{array}$ & $\begin{array}{l}\text { Kadın sağlık çalışanlarının } \\
\text { düzenli olarak Kendi } \\
\text { Kendine Meme Muayenesi } \\
\text { yapma oranlarının istenilen } \\
\text { düzeyde olmadığı ve KKMM } \\
\text { uygulamaları üzerinde Sağlık } \\
\text { İnanç düzeyleri yönünden } \\
\text { fark olduğu tespit edilmiştir. }\end{array}$ \\
\hline $\mathrm{Pak}^{30}$ & 2018 & 230 Kadın & Kesitsel tipte & $\begin{array}{l}\text { Araştırmacı } \\
\text { tarafindan } \\
\text { oluşturulan soru } \\
\text { formu ve } \\
\text { Champion'un } \\
\text { Sağlık İnanç } \\
\text { Modeli Ölçeği }\end{array}$ & $\begin{array}{l}\text { Katılımcıların Sağlık İnanç } \\
\text { Modeli Ölçeği’nin alt } \\
\text { boyutlarından duyarlılık } \\
\text { algılarının düşük, Mamografi } \\
\text { yararları ve KKMM yararları } \\
\text { algılarının yüksek düzeyde } \\
\text { olduğu saptanmıştır. }\end{array}$ \\
\hline Koçak $^{26}$ & 2019 & $\begin{array}{l}80 \text { İşitme engelli } \\
\text { kadın }\end{array}$ & $\begin{array}{l}\text { Yarı deneysel } \\
\text { tipte }\end{array}$ & $\begin{array}{l}\text { KKMM bilgi } \\
\text { düzeyi anket formu } \\
\text { ve Champion- } \\
\text { Sağlık İnanç } \\
\text { Modeli Ölçeği }\end{array}$ & $\begin{array}{l}\text { Eğitim öncesi, işitme engelli } \\
\text { kadınların çoğunun } \\
\text { KKMM'ni duymadığı ve } \\
\text { hiçbirinin yapamadı̆̆ı } \\
\text { belirlenmiştir. Eğitim } \\
\text { sonrası, deney grubundaki } \\
\text { kadınların KKMM beceri } \\
\text { basamaklarının çoğunu } \\
\text { yaptığı; kontrol } \\
\text { grubundakilerin ise oldukça } \\
\text { düşük oranda yaptığı } \\
\text { saptanmıştır. }\end{array}$ \\
\hline Çelik $^{25}$ & 2019 & $\begin{array}{l}70 \text { Görme engelli } \\
\text { kadın }\end{array}$ & $\begin{array}{l}\text { Yarı deneysel } \\
\text { tipte }\end{array}$ & $\begin{array}{l}\text { KKMM bilgi formu } \\
\text { ve Champion- } \\
\text { Sağlik İnanç } \\
\text { Modeli Ölçeği }\end{array}$ & $\begin{array}{l}\text { Eğitim öncesi, görme engelli } \\
\text { kadınların çoğunun } \\
\text { KKMM'yi duymadığı ve } \\
\text { yapamadığı belirlenmiştir. } \\
\text { Eğitim sonrası, sesli } \\
\text { betimlemeli eğitim } \\
\text { videosunu dinleyen } \\
\text { kadınların KKMM beceri } \\
\text { basamaklarının çoğunu } \\
\text { yaptığı, sesli betimleme } \\
\text { içermeyen eğitim videosunu } \\
\text { dinleyenlerin ise oldukça } \\
\text { düşük oranda yaptığı } \\
\text { saptanmıştır. }\end{array}$ \\
\hline Şahin ${ }^{16}$ & 2012 & $\begin{array}{l}258 \text { Kadın } \\
\text { akademisyen }\end{array}$ & Tanımlayıcı Tipte & $\begin{array}{l}\text { Araştırmacılar } \\
\text { tarafından } \\
\text { hazırlanan anket } \\
\text { formları }\end{array}$ & $\begin{array}{l}\text { Kadınların çalışma statüleri } \\
\text { ve medeni durumlarına göre } \\
\text { KKMM hakkında bilgi sahibi } \\
\text { olma durumları arasında } \\
\text { istatistiksel bir fark } \\
\text { saptanmıştır (p<0,05). Sonuç } \\
\text { olarak; kadınların KKMM } \\
\text { konusunda yeterli düzeyde } \\
\text { bilgi sahibi olmadıkları } \\
\text { saptanmıştır. }\end{array}$ \\
\hline Ateş $^{17}$ & 2014 & 285 Kadın & Tanımlayıcı Tipte & $\begin{array}{l}\text { Tanıtıcı bilgi formu } \\
\text { ve Champion } \\
\text { Sağlık İnanç } \\
\text { Modeli ölçeği }\end{array}$ & $\begin{array}{l}\text { Araştırmanın sonucunda } \\
\text { kadınların meme kanseri } \\
\text { erken tanı ve uygulama } \\
\text { yöntemleri hakkında } \\
\text { eksikliklerinin olduğu ve } \\
\text { eğitimlerle bu eksikliklerin }\end{array}$ \\
\hline
\end{tabular}




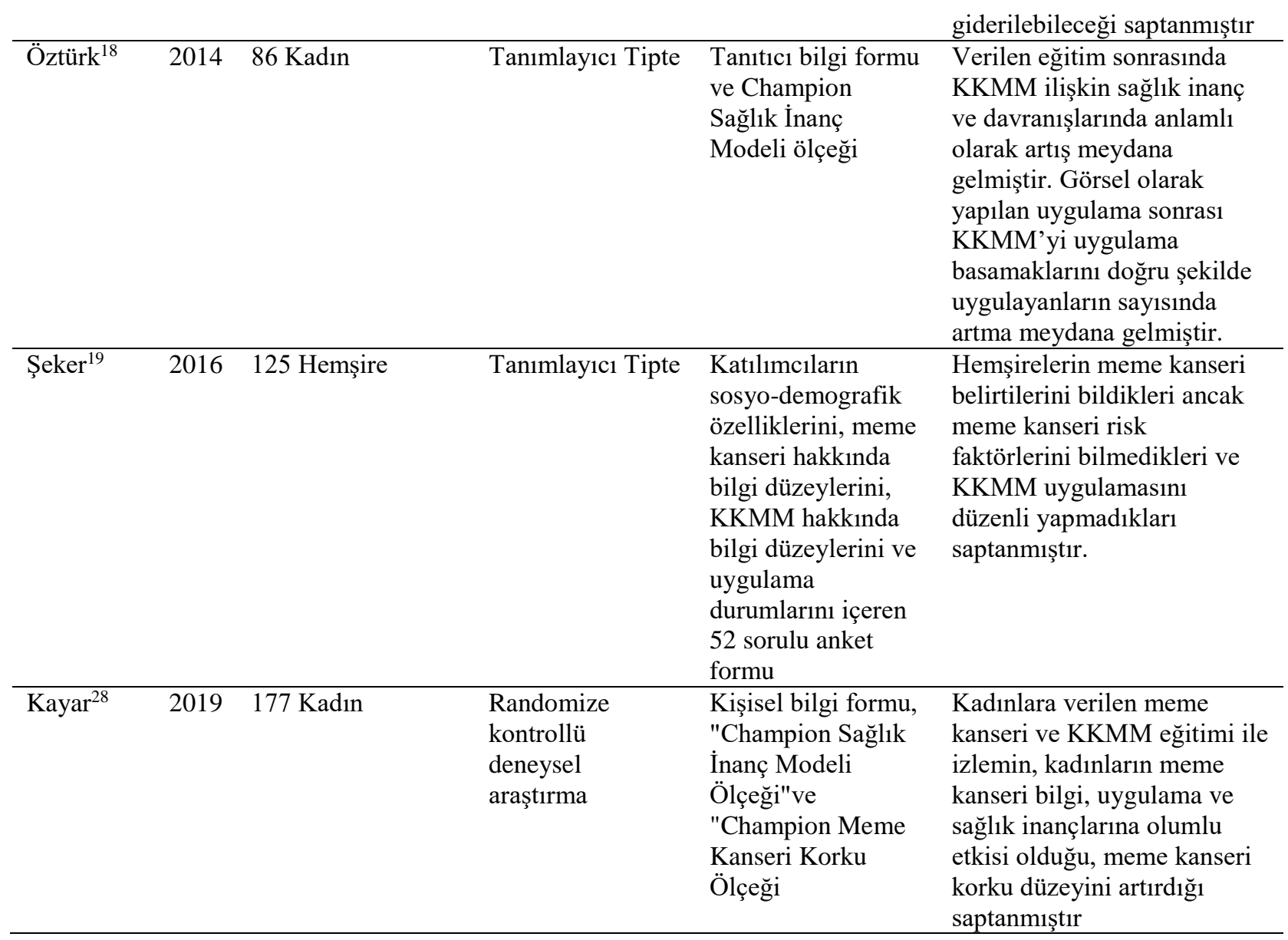

\section{Tartışma}

Çalışmada meme kanserinin erken teşhisinde önemi büyük olan KKMM yöntemi konusunda ebe ve hemşireler tarafindan yapılan lisansüstü tezler incelenmiştir. Tanımlayıcı tez çalışmaları incelendiğinde genellikle KKMM bilgi düzeyleri, yapma durumları, uygulamalarının değerlendirilmesi ve KKMM'nin sağlık inançlarına etkisini araştıran çalışmalar olduğu görülmektedir. ${ }^{11-22}$ Yarı deneysel olarak hazırlanan tezlerden iki tanesinde farklı eğitim modelleriyle verilen KKMM eğitimlerinin etkinliğinin değerlendirildiği diğer ikisinde ise işitme ve görme engelli bireyler için özel olarak hazırlanmıș eğitim videolarının KKMM üzerine etkisinin değerlendirildiği görülmektedir. ${ }^{23-26}$ Koçak ve Çelik tarafından Ebelik Anabilim Dalı'nda hazırlanan engelli bireylere yönelik eğitim videolarıyla KKMM'nin öğretilmesi tez çalışmalarının, önemli olduğu düşünülmektedir. ${ }^{25,26}$ Ebe ve hemşirelerin sağlığın korunması ve iyileştirilmesinde eğitici rollerini aktif kullanmaları ve halkın bilgi düzeyini arttırmaları gerekmektedir. ${ }^{27}$ Farklı eğitim ve farkındalık konularında da engelli bireylerin unutulmayıp, onlara özel olarak hazırlanan eğitim videolarıyla desteklenmeleri önem arz etmektedir. Deneysel tipte hazırlanan çalışmalar ise verilen KKMM eğitiminin sağlık inançlarına, algılanan sağlık durumuna ve meme kanseri korkusuna etkisini ölçmektedir. ${ }^{28,29}$ Deneysel olarak hazırlanan tezlerden biri doktora diğeri yüksek lisans tezidir. Aksoy ve ark. meme kanserinin erken tanısına yönelik engelleri araştırdığı çalışma sonucuna göre engellerin bilgi eksikliğinden dolayı olduğu bulunmuştur. ${ }^{30}$ Tanımlayıcı çalışmalarla ortaya konulan KKMM bilgi eksikliği ihtiyacının yapılan eğitimlerle ve eğitim sonrası kontrollerle kapatılacağ 1 ve KKMM'nin düzenli uygulanma oranlarının artacağ1 düşünülmektedir. Kesitsel tipte hazırlanan yüksek lisans tezinde kadınların $(n=230)$ KKMM hakkındaki sağlık inançları incelenmiştir. Kadınların duyarlılık algılarının düşük, mamografi yararları ve KKMM yararları algılarının yüksek düzeyde olduğu belirlenmiştir. ${ }^{31} \quad$ Tanımlayıcı-Müdahale çalışması olarak hazırlanan tezde, erken tanıya yönelik eğitim verilen kadınlarda 
$(\mathrm{n}=1000) \quad \mathrm{KKMM}$ yapma davranışları değerlendirilmiştir. Çalışma sonucuna göre eğitim öncesi ve sonrası anlamlı fark bulunmuştur. $^{32}$

Eğitim modeli kullanılan tez incelendiğinde akran eğitimi modeliyle, araştırmaya katılmaya gönüllü 15 öğrenci KKMM akran eğitimcisi olarak yeterlik kazandırıldıktan sonra, her biri akranı olan 10 kişiye ulaşarak KKMM eğitimi vermiştir. ${ }^{23}$ Eğitim öncesi bilgi puanlarıyla eğitimden üç hafta sonra bilgi puanları arasındaki artışta farkın anlamlı olduğu saptanmıştır $(p<0,005)$. Aynı șekilde öğrencilerin KKMM'yi eğitimin sonunda düzenli yapma durumlarındaki artış anlamlı bulunmuştur $(p<0,05)$. Eğitimde kullanılan akran eğitimi modelinin etkili bir yöntem olduğu görülmüştür.

KKMM ile ilgili bilgi düzeyi ölçen Gökpınar Çevik tarafından yapılan tez çalışmasında memede kitle şüphesiyle başvuran 62 kadın değerlendirilmiş ve kadınların KKMM hakkında bilgi düzeylerinin düşük olduğu, KKMM'yi her ay düzenli olarak yapmadıkları ve memelerindeki kitleyi tesadüfen fark ettikleri bulunmuştur. ${ }^{11}$ Ayrıca aynı tez çalışmasında kadınların çoğunluğunun KKMM'yi televizyon ve radyodan duyduğu ve sağlik profesyonellerinin konu hakkında bilgilendirmede etki payının düşük olduğu görülmüştür. ${ }^{11}$ Kadın sağlığının yükseltilmesi, korunması ve hastalıkların erken teşhisinde primer sorumluluğa sahip olan ebe ve hemșirelerin KKMM eğitimi noktasında etkililiklerinin arttırılması önerilebilir. Aynı zamanda kitle iletişim araçlarından öğrenilmenin yüksek olması göz önünde bulundurularak buralarda sürekli dönecek, dikkat çekici, etkili eğitim videolarının hazırlanması ve etkililiğin değerlendirilmesi çalışmaları yapılabilir.

Tanımlayıcı ve ilişkisel olarak Harputlu tarafından hazırlanan çalışmada 161 kadın mahkûmun sosyo-demografik değişkenlerinin KKMM'yi bilme, yapma oranı ve benlik sayg1 puanlarını etkileyip etkilemediği incelenmiştir. Kadınların benlik saygısı puanları 100 tam puan üzerinden 59,24 $\pm 18,94$ olarak saptanmıștır. Kadın mahkumların KKMM bilme puanları düşük, yapma davranışlarının yetersiz olduğu ve benlik saygısı ile KKMM uygulaması arasında ilişki olmadığ saptanmıştır. $^{13}$

Canbulat tarafindan tanımlayıcı olarak hazırlanan ve sağlık çalışanlarının KKMM ile ilgili sağlık inançlarını değerlendiren tez çalışmasında, sağlık çalışanlarının \%81,3'ünün KKMM yaptığı, \%21,9'unun düzenli olarak yaptığı saptanmıştır. Çalışma sonucuna göre KKMM uygulamasını hiç bilmeyenlerin \%2,6 oranında olması dikkat çekicidir. ${ }^{12}$ Meme kanseri erken tanısında tarama programlarının yürütülmesinde sağlık çalıșanlarının önemi bilindiğinden, öncelikli olarak hizmet içi ve sürekli eğitimlerle sağlı çalışanlarının bilgi ve becerilerinin arttırılması gerekmektedir. Öktem tarafından sağlıkla ilgili bölümler dışında okuyan öğrencilerin KKMM hakkındaki bilgi ve uygulama durumlarını değerlendiren çalışma sonucuna göre de öğrencilerin KKMM hakkında yeterli bilgiye sahip olmadıkları ve sadece \%28,5'inin doğru zamanda KKMM yaptığı bulunmuştur. ${ }^{16}$

Planlanan KKMM eğitim çalışmalarıyla konu hakkındaki farkındalığın ve uygulamanın artacağı düşünülmektedir. Benzer şekilde KKMM ile ilgili bilgi ve uygulama durumlarını belirlemek amaciyla yapılan tezlerin sonuçları bilgi eksikliğinin olduğunu ve KKMM yapma oranının az olduğunu göstermektedir. ${ }^{15,17-19,21,22,24} \mathrm{Bu}$ yüzden konu ile ilgili deneysel, yarı deneysel modelde çalışmalar yapılarak var olan bilgi ve uygulama eksikliklerinin kapatılmasına yönelik çalışmalar planlanması gerektiği düşünülmektedir.

Kadınların KKMM hakkında bilgi düzeylerini arttırmada hemşirenin eğitici rolünün etkinliğinin ölçüldüğü tez çalışmasında kadınların eğitim öncesi meme kanseri ve KKMM uygulamaları seçeneklerinden aldıkları puan ile eğitim sonrası aldıkları puan arasındaki artışın anlamlı olduğu saptanmıştır $(p<0,001) .{ }^{14}$ Benzer şekilde eğitim etkinliğiyle ilgili yapılan diğer tezlerde de eğitim sonrasında bilgi ve uygulama oranlarında artma olduğu görülmektedir. ${ }^{28,32}$ 
Tezlerde örneklem gruplarını sağlıklı, meme kanseri tanılı hasta, öğrenci, akademisyen, mahkûm, işitme engelli, görme engelli, memede kitle şikâyeti olan kadınlar oluşturmaktadır. Örneklem sayıları 62 (min)1000 (max) arasında değişmektedir (Tablo 1). Kersu tarafindan yapilan tanımlayıcı müdahale çalışmasında 1000 kişiye eğitim verilmesinin çalışmanın kalitesini arttırdığ düşünülmektedir. ${ }^{32}$

Araştırmalarda veri toplamada anket ve ölçekler kullanılmıştır (Tablo 1). Anketler, örneklem grubunun tanıtıcı özellikleri ve KKMM yapma ve değerlendirme sorularından oluşmaktadır. Çalışmalarda kullanılan ölçekler Champion Sağlık İnanç Modeli Ölçeği, Champion Meme Kanseri Korku Ölçeği, Nottingham Sağlik Profili (NHP) ve Coopersmith Benlik Saygis1 Ölçeği'dir. Tezlerin \%50'sinde Champion'un Sağlık İnanç Modeli Ölçeği'nin Türkçe formu kullanılmıştır. ${ }^{12,18,19,21,24-29,31}$

Champion'un Sağlık İnanç Modeli Ölçeği'ni kullanan tezlerin \%60'1 Gözüm ve Aydın'ın uyarladığı versiyonu kullanmıştır. Ölçek; Duyarlılık, Önemseme Ciddiyet, Sağlık Motivasyonu, KKMM yararları, KKMM Engelleri, KKMM Öz Etkililiği, Mamografi yararları ve Mamografi engelleri alt boyutlarından oluşmaktadır. Ölçeğin alt boyutları kendi içinde puanlandırılmakta ve ölçek toplam puanı üzerinden yorumlanmamaktadır. $\quad \mathrm{Bu}$ yüzden araştırmacılar çalışmanın amacına göre bazı alt boyutları çıararak kullanmışlardır. ${ }^{12,18,19,21,24-29,31}$

Champion'un Sağlık İnanç Modeli'ni kullanan tezler KKMM yapma durumlarına göre incelendiğinde ölçeğin alt boyutlarından olan KKMM yararları, KKMM öz etkililiği, sağlık motivasyonu alt boyutlarının yüksek olduğu; KKMM engel algılarının düşük olduğu görülmektedir. ${ }^{12,18,21,31} \mathrm{Bu}$ sonuçlar Champion'un Sağlık İnanç Modeli ile uyumludur. KKMM engel algılarının düşük olmas1, KKMM uygulama oranlarını arttırır. Dolayısıyla KKMM yarar algısı ve KKMM öz etkililik artmış olur.

Champion'un Sağlık İnanç Modeli doğrultusunda hazırlanan KKMM eğitiminin etkinliğinin değerlendirildiğ çalışmasında, eğitim sonrası KKMM ile ilgili sağlık inançlarında anlamlı düzeyde artış olduğu görülmektedir. ${ }^{24}$ Champion'un Sağlık İnanç Modeli Ölçeği kullanılarak KKMM ile ilgili verilen eğitimin sağlık inançlarına etkisinin belirlendiği çalışmalarda da eğitimin sağlık inançlarını olumlu düzeyde etkilediği bulunmuştur. ${ }^{19,26-29}$

Tez çalışmalarında kullanılan Champion Sağlık İnanç Modeli Ölçeği’nin meme kanseri tarama davranışlarının ortaya çıkarılmasında yaygin olarak tercih edilen ve etkili olan bir ölçek olduğu söylenebilir.

\section{Araştırmanın Kısıtlılıkları}

$\mathrm{Bu}$ araştırma, KKMM yönteminin tez adında geçtiği 20 lisansüstü tez ile sınırlıdır. Araştırmaya dahil edilen tezler 1985-2019 yılları arasındaki çalışmaları kapsamaktadır.

\section{Sonuç}

Kadın sağlığı sorunlarının başında kanserler yer almaktadır. Kadının sağlığının korunup iyileştirilmesi, erken tanı yöntemleriyle hastalığın teşhisinin hızlandirılması ve var olan sorunların çözülebilmesi için nitelikli ve ulaşılabilir sağlık bakım hizmeti sunumuna ihtiyaç vardır. $\mathrm{Bu}$ hizmetlerin sunumunda ebe ve hemşireler eğitici, danışman ve uygulayıcı rolleriyle sorumluluklarını yerine getiren sağllk profesyonelleridir. Araştırma sonucunda ebe ve hemşireler tarafindan KKMM ile ilgili yapılan tezlerin sayısının yetersiz olduğu söylenebilir. Özellikle konuyla ilgili doktora düzeyinde ve deneysel araştırmaların çok az olması olumsuz bir sonuç olarak değerlendirilmiştir.

- Bilgi eksikliğinin tespit edilmesinin yanında verilen eğitimlerle KKMM farkındalığı ve becerisi kazandıran lisansüstü tezlerinin sayılarının arttır1mas1,

- Eğitim programlarının içeriğinin Kanser Tarama Rehberlerine göre hazırlanarak standardizasyonun sağlanması, sosyal medyaya ulaşımın $\operatorname{arttığı~günümüzde~}$ danışmanlık hizmetlerinin online hizmetler şeklinde de planlanması, 
- Kitle iletişim araçlarından öğrenmenin yüksek olması göz önünde bulundurularak, buralarda sürekli dönecek, dikkat çekici, etkili eğitim videolarının hazırlanması ve etkililiğinin değerlendirilmesine yönelik tez çalışmaları yapılması,

- KKMM muayenesi takip, hatırlatma, not alma vb. gibi özelliklere sahip Türkçe akıllı telefon uygulamasının geliştirilmesi ve bu uygulamanın etkinliğini araştıran tez çalışmalarının yapılması,

- Sağlık profesyonellerinin hizmet içi ve sürekli eğitimlerle KKMM bilgi ve becerilerinin arttırılması,

- KKMM ile ilgili var olan bilgi ve uygulama eksikliklerinin kapatılmasına yönelik deneysel, yarı deneysel modelde çalışmaların planlanması,

- Verilen KKMM eğitimlerinde kullanılan yöntem ne olursa olsun kadinlarda farkındalık yaratması ve davranış değişikliğine neden olabilmesi önemlidir. Eğitim sonucunda geliştirilen olumlu sağlık davranışlarının devam edip etmediğinin, düzenli aralıklarla izlenmesi, bilgi ve davranış değiştirmeye yönelik desteğin sürdürülmesi,

- KKMM'yle ilgili eğitimlerin yaygınlaştırılması, kadınların muayeneyi yapma durumlarının hastane veya aile sağlığı merkezi başvurularında sorgulanmasını araştıran çalışmaların planlanmasi,

- Yapılacak çalışmaların kırsal kesimlerde ve daha fazla örneklem sayısıyla yürütülmesi,

- Kadınlara aile planlaması yöntemleri öğretilirken, mutlaka KKMM'ninde öğretilmesi ve kadının uygulama yapmasının sağlanması önerilmektedir.

\section{Araştırmanın Etik Yönü}

$\mathrm{Bu}$ araştırmanın etik kurul raporu bulunmamaktadır. Yüksek Öğretim Kurumu ulusal tez merkezi sayfasından erișim izni olan 20 tez kullanılmış, erişim izni olmayan tezler çalışmaya alınmamıştır.

\section{Yazar Katkıları}

Çalışma S.S. tarafından yapılıp, N.G.'nin katkı, denetleme ve onayıyla tamamlanmıştır.

\section{Çıkar Çatışması Beyanı}

Yazarların herhangi bir çıkar çatışması bulunmamaktadır.

\section{Araştırma Desteği}

Çalışmayı maddi olarak destekleyen kişi/kuruluş yoktur.

\section{Beyanlar}

Çalışma daha önce herhangi bir yerde sunulmamıştır.

\section{Hakem Değerlendirmesi}

Diş bağımsız.

\section{Kaynaklar}

1. Bray F, Ferlay J, Soerjomataram I, Siegel RL, Torre LA, Jemal A. "Global Cancer Statistics 2018: GLOBOCAN Estimates of İncidence and Mortality Worldwide for 36 Cancers in 185 Countries." CA: A Cancer Journal For Clinicians. 2018;68(6):394-424.

2. Sağlık İstatistikleri Yıllığı. T.C. Sağlık Bakanlı̆̆ı Yayın No:1106. Kuban Matbaacılık ve Yayıncılık, Ankara. 2017.

3. Akram M, Iqbal M, Daniyal M, Khan AU. "Awareness and current knowledge of breast cancer." Biological research 2017;50(1):33

4. Jamal MY. "Knowledge, screening, and practices surrounding 1raqi female breast cancer: an observational cross-sectional survey study." Prensa Med Argent. 2020;106:1

5. Türkiye Halk Sağlığı Kurumu. Dünya'da ve Türkiye'de Meme Kanseri Tarama Programları. 2018. https://hsgm.saglik.gov.tr/depo/birimler/kanserdb/yayinlar/raporlar/ Ulusal Kanser KontrolPlani2013_2018.pdf. 08 Şubat 2020 tarihinde erişildi.

6. Sağlık Bakanlığı. Türkiye Halk Sağlığı Kurumu, Meme Kanseri Tarama Programı Ulusal Standartları. https://hsgm.saglik.gov.tr/tr/kanser-taramalari. 1 Ocak 2020 tarihinde erişildi.

7. American Cancer Society. Cancer Facts and Figures. https://www.cancer.org/research/cancer-facts-statistics/allcancer-facts-figures/ cancer-facts-figures-2015.htm. 07 Şubat 2020 tarihinde erişildi.

8. Gençtürk N. "İstanbul'da bir sağlık kuruluşunda çalışan kadın sağlık profesyonellerinin kendi kendine meme muayenesini bilme ve uygulama durumları. Sağllk Bilimleri ve Meslekleri Dergisi. 2015; 2(2):209-216.

9. Kozan R, Tokgöz VY. "Türkiye'de meme kanseri farkındalığı ve tarama programı." ACU Sağllk Bilimleri Dergisi. 2016;(4):185188

10. Gençtürk N, Demirezen E, Ay F. "Health beliefs of midwifery students at Istanbul University about breast cancer and breast self-examination acknowledgements." Journal of Cancer Education. 2017;32(4), 784-789.

11. Gökpınar Çevik C. Memede Kitle Şüphesiyle Hastaneye Başvuran Kadınların Meme Kanseri ve Kendi Kendine Meme Muayenesi ile İlgili Bilgi Düzeyleri ve Kitlenin Fark Edilmesinde Kendi Kendine Meme Muayenesinin Etkisi, Afyon Kocatepe Üniversitesi, Sağlık Bilimleri Enstitüsü, Yüksek Lisans Tezi. Afyon; 2003.

12. Canbulat N. Sağlık Çalışanlarının Meme Kanseri, Kendi Kendine Meme Muayenesi ve Mamografiye İlişkin sağlik İnançlarının İncelenmesi, Atatürk Üniversitesi, Sağlık Bilimleri Enstitüsü, Yüksek Lisans Tezi. Erzurum; 2006.

13. Harputlu D. Kadın Mahkumların Benlik Saygısı ve Kendi Kendine Meme Muayenesi İlişkisi, Ege üniversitesi, Sağlık Bilimleri Fakültesi, Yüksek lisans Tezi, İzmir; 2005.

14. Arslan M. Kadınların Meme Kanseri ve Kendi Kendine Meme Muayenesi Bilgi Düzeyini Arttırmada Hemşirenin Eğitici Rolünün Etkinliği, Afyon Kocatepe Üniversitesi, Sağlık Bilimleri Enstitüsü, Yüksek Lisans Tezi. Afyon; 2007. 
15. Taşçı A. Bolu İl Merkezindeki Aile Sağlığı Merkezlerine Başvuran 40 Yaş Üstü Kadınlarda ve Bu Merkezlerde Çalışan Hemşirelerde Kendi Kendine Meme Muayenesi Bilgi ve Uygulamalarının Karşılaştırılması, Abant İzzet Baysal Üniversitesi, Sağlık Bilimleri Enstitüsü, Yüksek Lisans Tezi, Bolu; 2008.

16. Öktem A. Afyon Kocatepe Üniversitesi'nde Sağlıkla İlgili Bölümler Dışındaki 3. ve 4. Sınıf Kız Öğrencilerin Meme Kanseri ve Kendi Kendine Meme Muayenesi Hakkında Bilgi Düzeylerinin ve Uygulama Durumlarının Belirlenmesi, Afyon Kocatepe Üniversitesi, Sağlık Bilimleri Enstitüsü, Yüksek Lisans Tezi, Afyon; 2012.

17. Şahin T. Adıyaman Üniversitesi'nde Çalışan Bayanların Kendi Kendine Meme Muayenesiyle İlgili Bilgi ve Uygulamaları, Firat Üniversitesi, Sağlık Bilimleri Enstitüsü, Yüksek Lisans Tezi, Elazı $\breve{g} ; 2012$.

18. Ateş S. Kadınların Kendi Kendine Meme Muayenesi Uygulamalarının Değerlendirilmesi, İstanbul Bilim Üniversitesi Sağlık Bilimleri Enstitüsü, Yüksek Lisans Tezi, İstanbul; 2014.

19. Öztürk Ş. Bir Fabrikada Çalışan Kadınlara Verilen Eğitimin Kendi Kendine Meme Muayenesine İlişkin Sağlık İnanç ve Davranışlarına Etkisi, Ege Üniversitesi, Sağlık Bilimleri Enstitüsü, Yüksek Lisans Tezi, İzmir; 2014.

20. Şeker E. Sakarya Üniversitesi Eğitim ve Araștırma Hastanesi Merkez Kampüsünde Çalışan Hemşirelerin Meme Kanseri ve Kendi Kendine Meme Muayenesi Konusundaki Bilgi Düzeylerinin ve Uygulama Durumlarının Belirlenmesi, Düzce Üniversitesi, Sağlık Bilimleri Enstitüsü, Yüksek Lisans Tezi, Düzce; 2016.

21. Ceylan S. Kadın Sağlık Çalışanlarının Kendi Kendine Meme Muayenesi Uygulamalarına Sağlık İnanç Düzeylerinin Etkisi, Üsküdar Üniversitesi, Sağlık Bilimleri Enstitüsü, Yüksek Lisans Tezi, İstanbul; 2017.

22. Akyolcu N. Kadınların Meme Kanseri ve Kendi-Kendine Meme Muayenesi Hakkındaki Sağlık Bilgisi Düzeylerinin Ölçülmesi, İstanbul Üniversitesi, Sağlık Bilimleri Enstitüsü, Doktora Tezi, İstanbul; 1985.

23. Tuna A. Üniversite Öğrencilerinin Kendi Kendine Meme Muayenesini Öğrenmelerinde Akran Eğitimi Modelinin Etkinliğinin İncelenmesi, Dokuz Eylül Üniversitesi, Sağlık Bilimleri Enstitüsü, Yüksek Lisans Tezi, İzmir; 2002.

24. Elik Z. Sağlık İnanç Modeli Doğrultusunda Verilen Eğitimin Kadınların Kendi Kendine Meme Muayenesi Uygulamaları Üzerine Etkisi, Kocaeli Üniversitesi Sağlık Bilimleri Enstitüsü, Yüksek Lisans Tezi, Kocaeli; 2006.

25. Koçak M. İşaret Dili İle Hazırlanan Eğitim Videosunun İşitme Engelli Kadınların Kendi Kendine Meme Muayenesi Üzerine Etkisi, Manisa Celal Bayar Üniversitesi, Sağlık Bilimleri Enstitüsü, Yüksek Lisans Tezi, Manisa; 2019.

26. Çelik S. Sesli Betimleme İle Hazırlanan Eğitim Videosunun Görme Engelli Kadınların Kendi Kendine Meme Muayenesi Üzerine Etkisi, Manisa Celal Bayar Üniversitesi, Sağlık Bilimleri Enstitüsü, Yüksek Lisans Tezi, Manisa; 2019.

27. Koçak M, Celik S, İldan Çalım S, Cambaz Ulaș, S, Karadal A. İsitme Engelli Kadınlara Verilen Kendi Kendine Meme Muayenesi (KKMM) Eğitiminin Etkinliğinin Değerlendirilmesi. STED. 2019;28 (5): 320-326. DOI: 10.17942/sted.438518

28. Duran Ö. Kendi Kendine Meme Muayenesi ile İlgili Verilen Planlı Eğitimin Kadınların Sağlık İnançları ve Algılanan Sağlık Durumlarına Etkisi, Cumhuriyet Üniversitesi, Sağlık Bilimleri Enstitüsü, Doktora Tezi, Sivas: 2008.

29. Kayar N. Meme Kanseri ve Kendi Kendine Meme Muayenesi Eğitiminin Meme Kanseri Korkusu ve Sağlık İnançlarına Etkisi, Ordu Üniversitesi, Sağlık Bilimleri Enstitüsü, Yüksek Lisans Tezi, Ordu; 2019

30. Aksoy YE, Turfan EÇ, Sert E, Mermer G. "Meme Kanseri Erken Tanı Yöntemlerine İlişkin Engeller." J Breast Health. 2019;11: 26-30.

31. Pak N. Kars/Sarıkamıș İlçesinde Yaşayan Kadınların Kendi Kendine Meme Muayenesi Hakkındaki Sağlı İnançlarının İncelenmesi, Kafkas Üniversitesi, Sağlık Bilimleri Enstitüsü, Yüksek Lisans Tezi, Kars; 2018.

32. Kersu Ö. Meme Kanserinin Erken Tanısına Yönelik Eğitim Verilen Kadınlarda Kendi Kendine Meme Muayenesi (KKMM) Yapma Davranışının Değerlendirilmesi, Eskişehir Osmangazi Üniversitesi, Sağlık Bilimleri Enstitüsü, Yüksek Lisans Tezi, Eskişehir; 2010. 